\title{
Pendampingan Pengelolaan dan Pembinaan Kelompok Bina Keluarga Lansia (BKL) Melalui Kegiatan Pengabdian pada Masyarakat Dosen dan Mahasiswa di Wilayah Jakarta Timur
}

\author{
Elferida Sormin ${ }^{1}$, Rosintan Napitupulu ${ }^{2}$, Novlinda Susi Andrianawati ${ }^{3}$, \\ Ronny Gunawan ${ }^{4}$, Renatha Ernawati ${ }^{5}$, Eustalia Wigunawati ${ }^{6}$ \\ Universitas Kristen Indonesia 1,2,3,4,5,6 \\ Elferida.sormin@uki.ac.id
}

\begin{abstract}
Abstrak
Jumlah penduduk lansia Indonesia saat ini yang sudah mencapai persentase 9,6\% dari total jumlah penduduk menjadi perhatian semua stakeholder termasuk pemerintah dan akademisi di perguruan tinggi. UKI yang berkedudukan wilayah terdapat di Jakarta Timur menjadi salah satu dari lima perguruan tinggi yang dihunjuk langsung oleh pemerintah provinsi DKI Jakarta melalui Dinas Pemberdayaan Perlindungan Anak dan Pengendalian Penduduk (Dinas PPAPP) Provinsi DKI Jakarta untuk melakukan kegiatan KKN Tematik, yang oleh UKI dilaksanakan dalam bentuk kegiatan pengabdian kepada masyarakat dengan jenis kegiatan pendampingan pengelolaan dan pembinaan kelompok Bina Keluarga Lansia (BKL). Adapun yang menjadi tujuan dari kegiatan pengabdian ini adalah untuk menggairahkan kembali kelompok-kelompok BKL yang sudah pernah terbentuk, namun tidak ada aktifitas alias mati suri. Bekerjasama dengan Sudin PPAPP Jakarta Timur, Tim UKI diarahkan untuk melakukan pendampingan dan pembinaan kepada kelompok BKL di RW 05 Kelurahan Cililitan. Berdasarkan data yang diperoleh, terdapat sekitar seratus orang lansia yang menjadi anggota tetap BKL di RW 05 Kelurahan Cililitan, yang pada saat awal dibentuk memiliki struktur kepengurusan yang sah dan berbagai macam program. Namun beberapa waktu terakhir dengan adanya pergantian kepengurusan, aktifitas berkurang bahkan struktur kepengurusan juga belum memeroleh pengesahan dari Kelurahan. Hal ini disebabkan oleh beberapa faktor, di antaranya tidak tersedianya cukup banyak waktu oleh pengurus yang terbaru untuk melakukan koordinasi. Melalui kegiatan pendampingan dan pembinaan yang dilakukan oleh tim UKI bekerjasama dengan dinas PPAPP diperoleh beberapa hasil, di antaranya semakin bertambahnya pengetahuan para kader tentang kelanjutusiaan yang diperoleh dari kegiatan sharing dan diskusi, terbentuknya kepengurusan kelompok BKL yang disahkan oleh Lurah Kelurahan Cililitan dan adanya program terencana kelompok BKL
\end{abstract}

Kata kunci: Bina Keluarga Lansia, Pengabdian kepada Masyarakat, Kelanjutusiaan

\begin{abstract}
The current population of elderly Indonesians who have reached $9.6 \%$ of the total population is the concern of all stakeholders including the government and academics in tertiary institutions. UKI domiciled in East Jakarta is one of five tertiary institutions appointed directly by the provincial government of DKI Jakarta through the Office of the Empowerment of Child Protection and Population Control (Dinas PPAPP) of DKI Jakarta Province to carry out Thematic Community Service Program activities, which is conducted by UKI in the form of community service activities with the type of mentoring management and fostering the Elderly Family Development (BKL) group. The purpose of this community service activity is to revive BKL groups that have already been formed, but there is no suspended activity. In collaboration with East Jakarta PPAPP Sub-dept., The UKI Team was directed to provide assistance and guidance to the BKL group in RW 05, Cililitan Village. Based on the data obtained, there are about one hundred elderly people who become permanent BKL members in RW 05, Cililitan Sub-District, which at the beginning were formed having a legal management structure and various programs. However, recently with the change of management, activities have been reduced, even the management structure has not yet received approval from the Kelurahan. This is caused by several factors, including the unavailability of enough time for the latest management to coordinate. Through the mentoring and coaching activities carried out by the UKI team in collaboration with the PPAPP service, several results were obtained, including the increasing knowledge of cadres about humanity obtained from sharing and discussion activities, the formation of
\end{abstract}


the management of the BKL group which was endorsed by the Kelurahan of Cililitan and the planned group program $B K L$

Keywords: Elderly Family Development, Community Service, Continuation

\section{Pendahuluan}

Indonesia saat ini memiliki jumlah penduduk yang banyak dari segi kuantitas, di mana menurut data Survei Penduduk Antar Sensus/Supas 2015 terdapat sekitar 255,18 juta jiwa. Sesungguhnya angka ini dapat menjadi asset Negara jika diimbangi dengan kualitas yang mumpuni. Berbagai upaya dilakukan oleh pemerintah di antaranya dengan memperhatikan komposisi penduduk. Penduduk lansia atau lanjut usia menjadi salah satu aspek yang menjadi perhatian pemerintah.(BKKBN, 2019)

Jumlah penduduk lansia Indonesia saat ini sekitar 21 juta atau sekitar 9,6\% dari total penduduk Indonesia. Lansia merupakan orang per orang yang oleh karena usianya secara alamiah mengalami kemunduran baik dari segi fisik maupun psikologis. Terdapat beberapa penyakit yang sering dialami oleh para lansia, di antaranya adalah hipertensi, diabetes melitus, masalah gigi dan mulut, stroke dan yang lainnya,(Riskesdas, 2013). Ditambah lagi timbulnya gangguan pendengaran, penglihatan, pendengaran dan gangguan dalam hal mengingat, hilang keseimbangan, depresi dan yang lainnya (Supas, 2015). Lansia yang sehat akan mampu mandiri dan produktif, namun sebaliknya jika lansia tidak sehat akan semakin cepat menjadi tanggungan keluarga dan anak-anaknya.(Kamila, N.,2018). Bila anak-anak dan keluarga tidak mampu mengurus orangtua (lansia) yang tidak sehat fisik atau psikologis, maka secara otomatis akan menjadi tanggungan negara.(Dinas PPAPP, 2018).

Untuk mengantisipasi masalah-masalah terkait dengan lansia, maka diperlukan pemahaman secara menyeluruh dari semua stake holder tentang ciri-ciri lansia dan menyadari bahwa lansia mempunyai masalah dan kebutuhan khusus dikarenakan konsisi fisik dan psikologis. Salah satu program pemerintah melalui BKKBN yang menugaskan Direktorat Bina Ketahanan Keluarga Lansia dan Rentan adalah pembentukan dan pembinaan kelompok Bina Keluarga Lansia (BKL). Adapun kelompok BKL merupakan keluarga yang mempunyai Lansia dan Lansia itu sendiri. Pendampingan terhadap kelompok BKL dipandang sangat relevan karena keluarga lansia merupakan unsur yang pertama sekali dan secara langsung bersentuhan dengan para Lansia.

Untuk memaksimalkan program pembinaan terhadap kelompok BKL ini, tidak cukup hanya oleh pemerintah. Namun sinergitas semua stake holder 
mulai dukungan dari lembaga masyarakat dan akademisi juga sangat diperlukan. Oleh sebab itu, Dinas PPAPP memberikan penunjukan langsung terhadap lima universitas di wilayah DKI Jakarta meliputi bagian Timur oleh Universitas Kristen Indonesia, Barat oleh Universitas Mercu Buana, Utara oleh Universitas Tujuh Belas Agustus 1945, Selatan oleh Univesitas Muhammadyah Dr. Hamka, Pusat oleh Universitas Yarsi. Adapun Program yang diusung melalui penunjukan ini adalah Pendampingan Pengelolaan dan Pembinaan BKL Melalui Peran KKN Perguruan Tinggi.

Universitas Kristen Indonesia yang berlokasi di Jakarta Timur merupakan universitas swasta yang memiliki keperdulian terhadap masalah-masalah kependudukan. Program yang diusung oleh Dinas PPAPP melalui KKN Tematik dilaksanakan oleh UKI melalui kegiatan Pengabdian pada Masyarakat Dosen dan Mahasiswa yang dikoordinir oleh Lembaga Penelitian dan Pengabdian pada Masyarakat (LPPM), karena dalam kurikulum UKI belum mengakomodasi kegiatan KKN secara menyeluruh.

Provinsi DKI Jakarta secara umum telah banyak yang memiliki kelompok Bina Keluarga Lansia (BKL), termasuk wilayah Jakarta Timur secara khusus di Kelurahan Cililitan. Dari kelompok-kelompok BKL ini banyak yang secara aktif melakukan kegiatan pembinaan dan pendampingan baik dengan bantuan pihak eksternal maupun secara mandiri. Namun tidak bisa dipungkiri juga bahwa di antara BKL yang aktif dan mandiri, banyak juga kelompok BKL yang sejak dibentuk sampai saat ini tidak memiliki aktifitas alias mati suri. Oleh karena itu, melalui program kerjasama Dinas PPAPP bersama Perguruan Tinggi kali ini difokuskan pada kelompok BKL yang dianggap mati suri untuk kembali aktif bahkan mampu mandiri menghasilkan keluarga Lansia dan Lansia hebat dan tangguh.

TUJUAN

1. Umum

Meningkatkan pengetahuan dan kesadaran masyarakat tentang program Kependudukan, Keluarga Berencana dan Pembangunan Keluarga (KKBPK) secara khusus tentang kelanjutusiaan melalui kegiatan Pengabdian pada Masyarakat Dosen dan Mahasiswa.

2. Khusus

a.Melakukan pembentukan, pengelolaan dan pendampingan Poktan BKL

b.Mensosialisasikan materi tentang kelanjutusiaan melalui program pengabdian pada masyarakat Dosen dan Mahasiswa

c. Penerapan teori dan ilmu pengetahuan tentang kelanjutusiaan dalam menangani permasalahan yang terjadi

d.Dosen dan Mahasiswa dapat 
mengimplementasikan satu dari tri darma perguruan tinggi yaitu pengabdian pada masyarakat

\section{Sasaran}

Berdasarkan arahan Sudin PPAPP, maka masyarakat yang menjadi sasaran program pendampingan poktan BKL oleh Dosen dan Mahasiswa UKI adalah Poktan BKL di RW 05 Kelurahan Cililitan, Jakarta Timur

\section{METODE}

Adapun metode pendampingan dan pembinaan yang dilakukan adalah sebagai berikut:

1. Persiapan

a. Tahapan persiapan meliputi audiensi kepada Sudin PPAPP Jakarta Timur terkait pemilihan lokasi di mana kelompok BKL akan didampingi

b. Melakukan kunjungan dan permohonan ijin ke Kelurahan yang ditunjuk

2. Inti

a. Melakukan diskusi dengan para Kader BKL tentang apa dan bagaimana program BKL yang sudah pernah dilakukan

b. Melakukan sosialisasi dan pendampingan terkait permasalahan yang dihadapi oleh BKL

c. Melakukan follow up pendampingan

\section{Pembahasan}

Secara umum dalam pelaksanaan kegiatan, Tim UKI merasakan kerjasama yang sangat baik dari semua stake holder (mulai dari sudin PPAPP, Satpel tingkat Kecamatan Kramat Jati, Kelurahan Cililitan, Ketua PKB Kelurahan, Ketua RW, bahkan para kader dan juga masyarakat RW 05 secara khusus para lansia dan keluarga lansia).

Pada saat pelaksanaan kegiatan inti tanggal 29 Oktober 2019 yang sasarannya adalah keluarga lansia dan lansia itu sendiri, acara dibuka oleh kepala Lurah Kelurahan Cililitan yang menyatakan sangat bersyukur dan merasa sangat senang dengan program ini. Acara dihadiri oleh sekitar 100 orang yang terdiri dari keluarga lansia dan lansia itu sendiri. Setelah selesai sambutan dari kepala Lurah, para lansia menyanyikan mars lansia secara bersama-sama.

Pemaparan tentang bahagia menjalani masa usia emas oleh dosen Bimbingan Konseling FKIP UKI membuat para Lansia menjadi bersemangat, karena sesungguhnya usia lanjut itu adalah anugerah pemberian Sang Maha Pencipta. Para 
Lansia diajak berdiskusi dan bernyanyi dengan gerakan-gerakan ringan namun asyik.

Setelah pemaparan dari dosen dan mahasiswa BK FKIP UKI, acara dilanjutkan dengan pemeriksaan dasar kesehatan oleh program studi fisioterapi kerjasama dengan Puskesmas Cililitan seperti pemeriksaan tekanan darah, pemeriksaan kadar gula, dan kolesterol. Selain itu Fisioterapi juga mengajak para lansia untuk melakukan gerakan-gerakan dasar seperti bagaimana cara menarik nafas yang benar dan sehat, melakukan gerakan kaki dan tangan untuk menjaga keseimbangan.

\section{Hasil Kegiatan}

Hasil yang diperoleh dari kegiatan pengabdian kepada masyarakat dalam bentuk pendampingan dan pembinaan kelompok Bina Keluarga Lansia (BKL) adalah sebagai berikut:

1. Adanya SK Kepengurusan/Kader Poktan BKL yang diterbitkan oleh Lurah di Kelurahan Cililitan, Jakarta Timur

SK kepengurusan/kader Poktan BKL sedang dalam tahap pengusulan nama-nama pengurus yang baru untuk selanjutnya dibuatkan SK oleh Lurah Cililitan, sehubungan dengan kepengurusan yang sebelumnya menyatakan tidak bisa maksimal memberikan perhatian maupun waktu oleh karena kesibukan pekerjaan.

2. Meningkatnya pengetahuan kader tentang kelanjutusiaan

Pada waktu pelaksanaan diskusi dengan para kader di rumah salah seorang kader (Ibu Yuni), dilakukan sharing tentang apa itu kelanjutusiaan. Saling tukar informasi tentang apa permasalahan-permasalahan

Lansia dilakukan, dan dari hasil diskusi dapat disimpulkan bahwa pengetahuan para kader tentang Lansia dan bagaimana keluarga lansia mendampingi dan memperlakukan anggota keluarga yang lansia sudah baik, baik pengetahuan tentang kebutuhan lansia secara fisik maupun psikis.

3. Tersusunnya program dan rencana kerja dari kader poktan $\mathrm{BKL}$

Program rutin dalam rangka pembinaan dan pendampingan kelompok BKL kerjasama UKI dengan Kelurahan Cililitan adalah pendampingan dan pelatihan 
gerakan dasar fisik pada lansia oleh dosen dan mahasiswa Fisioterapi, yang dilaksanakan secara rutin satu kali dalam satu bulan dengan waktu yang bersamaan dengan pelaksanaan posyandu lansia.

4. Ditemukannya langkah-langkah taktis yang akan menjadi rekomendasi untuk keberlanjutan kelompok BKL.

Dari pengalaman dan pengamatan ketika melakukan pendampingan terhadap kelompok BKL di RW 05, maka terdapat beberapa rekomendasi Perguruan Tinggi dalam rangka keberlanjutan kelompom BKL, yakni:

a. Perlu adanya sarana dan prasarana yang ramah lansia

Rekomendasi ini timbul dari pengalaman tim melakukan kegiatan di gedung paud RW 05 yang memiliki ukuran tidak begitu luas sehingga harus menggelar tenda di luar gedung paud dengan perlengkapan dan alat keselamatan yang minim, sehingga ketika diterpa angin tiang penyangga sewaktu-waktu bisa jatuh dan untungnya tidak menimpa para peserta. Ketika ditanyakan mengapa tidak menggunakan RPTRA kelurahan, diperoleh keterangan bahwa para lansia memiliki kesulitan untuk akses transportasi dikarenakan jarak yang jauh antara rumah para lansia dengan RPTRA. Untuk ini diperlukan sarana transportasi yang khusus antara jemput para lansia ketika kegiatan pendampingan berlangsung.

b. Perlu diadakan program Home Visit

Terdapat beberapa lansia yang sesungguhnya sangat ingin bergabung dalam kegiatan kelompok BKL, namun oleh karena keterbatasan kemampuan fisik membuat mereka akhirnya memilih untuk tidak datang. Maka terkait hal ini direkomendasikan jika memungkinkan supaya petugas terkait kesehatan melakukan kunjungan pemeriksaan rutin terhadap para lansia yang sedang tidak berdaya oleh karena kelemahan fisik dan memberikan saran pengobatan sampai pada akhirnya lansia tersebut pulih dan dapat bergabung dengan sesama lansia di kelompok BKL.

Kegiatan home visit juga dapat dilakukan oleh para kader dan anggota kelompok BKL melalui 
program kumpul bersama di tempat lansia yang sedang mengalami kelemahan fisik sambil mengaji bersama contohnya.

\section{c. Pemberian penghargaan kepada BKL aktif dan mandiri}

Pemberian penghargaan sebagai stimulan kepada kelompok BKL yang aktif dan mandiri diharapkan dapat membangkitkan semangat para kader untuk tetap menjalankan program-program terkait BKL.

\section{c. Memfasilitasi ruang komunikasi terbuka antara lansia dan para pemuda}

Salah satu rekomendasi yang dipandang perlu adalah membuka ruang komunikasi antara para lansia dengan para pemuda yang berada di sekitar para lansia. Adapun yang menjadi tujuan dari program ini diharapkan adanya komunikasi dua arah antara lansia dan pemuda, di mana para lansia dapat menceritakan pengalamanpengalaman mereka yang secara psikologis lansia sangat membutuhkan hal ini, di mana mereka diberi ruang untuk bicara, bercerita dan ada orang lain yang mendengar. Dari sisi pemuda, dengan adanya komunikasi dua arah ini diharapkan akan menggugah pemuda dan menyadarkan mereka bahwa suatu saat pemuda juga akan melewati masa-masa lansia, sehingga secara psikologi mereka juga secara tidak langsung sudah dipersiapkan dalam menjalani masa lansia.

\section{Luaran}

Kegiatan pendampingan kelompok BKL yangsudah dilaksanakan oleh tim UKI sebagai pelaksana yang dihunjunk dan dipercayakan oleh Dinas PPAPP diliput oleh Media Indonesia dan juga sedang dipersiapkan untuk dipublikasi di jurnal pengabdian kepada masyarakat LPPM UKI

\section{KESIMPULAN}

Dari kegiatan pengabdian kepada masyarakat dalam rangka pendampingan dan pembinaan kelompok Bina Keluarga Lansia (BKL) di RW 05 Kelurahan Cililitan, Kecamatan Kramat Jati, Jakarta Timur diperoleh kesimpulan bahwa dalam rangka pemberdayaan masyarakat secara khusus untuk kelompok Lansia dibutuhkan penanganan yang serius melalui sinergi dari semua stake holder. Melakukan pembinaan yang berkelanjutan mellaui program yang sudah terencana menjadi kunci utama dalam pencapaian kelompok lansia yang produktif, hebat dan tangguh. 
UCAPAN TERIMAKASIH

Ucapan terimakasih kepada semua pihak yang mendukung terlaksananya kegiatan pengabdian kepada masyarakat dalam rangka pemdampingan dan pembinaan kelompok Bina Keluarga Lansia (BKL) di RW 05 Kelurahan Cililitan, Kecamatan Krama Jati, Jakarta Timur, di antaranya:

1. Dinas PPAPP Provinsi DKI Jakarta

2. Sudin PPAPP Jakarta Timur

3. Satpel Kecamatan Kramat Jadi di bidang kependudukan

4. Kelurahan Cililitan

5. PKB Kelurahan Cililitan

6. RW 05 Kelurahan Cililitan

7. Para Kader pengurus BKL RW 05 Kelurahan Cililitan

8. Rektor UKI beserta jajarannya

9. Ketua LPPM UKI beserta jajarannya

10. Kaprodi DIII Fisioterapi, Fakultas Vokasi UKI

11. Kaprodi Bimbingan Konseling FKIP UKI

12. Para dosen dan mahasiswa
Badan Penelitian dan Pengembangan Kesehatan Kementerian Kesehatan RI. 2013. Riset Kesehatan Dasar Provinsi Jawa Timur. Badan Penelitian dan Pengembangan

BKKBN, (2019). Pedoman Pengelolaan $B K L$. Jakarta

BPS. (2015). Survei Penduduk Antar Sensus 2015. Jakarta: Badan Pusat Statistik.Harley, D. (2008). Common Hoaxes and Chain Letters. San Diego: ESET, LLC.

Kamila, N. (2018). Pengembangan kelompok Bina Keluarga Lansia (BKL) dalam mewujudkan lansia sehat di Desa Besuki(Doctoral dissertation, UIN Sunan Ampel Surabaya)..

\section{REFERENSI}




\section{Foto-Foto Kegiatan Pkm "Pendampingan Pengelolaan Dan Pembinaan Kelompok Bina Keluarga Lansia (Bkl) Melalui Kegiatan Pengabdian Pada Masyarakat Dosen Dan Mahasiswa Di Wilayah Jakarta Timur"}

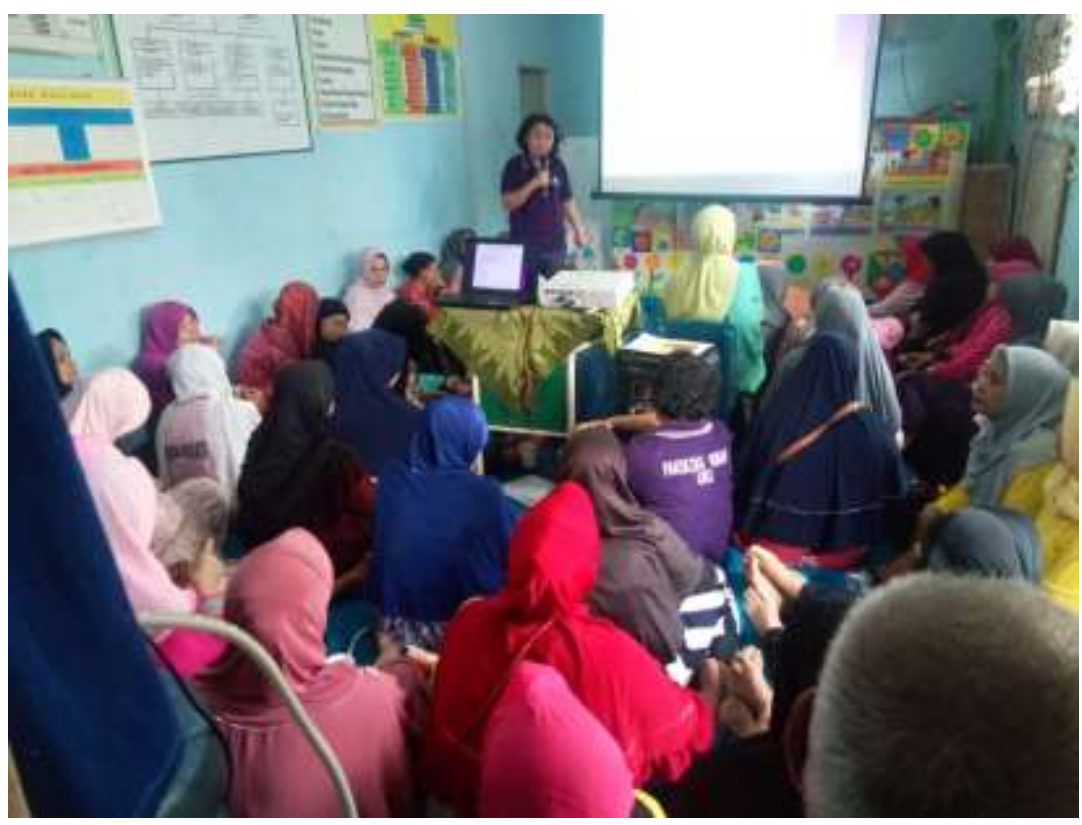

Foto 1.

Sosialisasi tentang Kesehatan Fisik Lansia oleh Dosen Prodi DIII Fisioterapi Fakultas Vokasi UKI

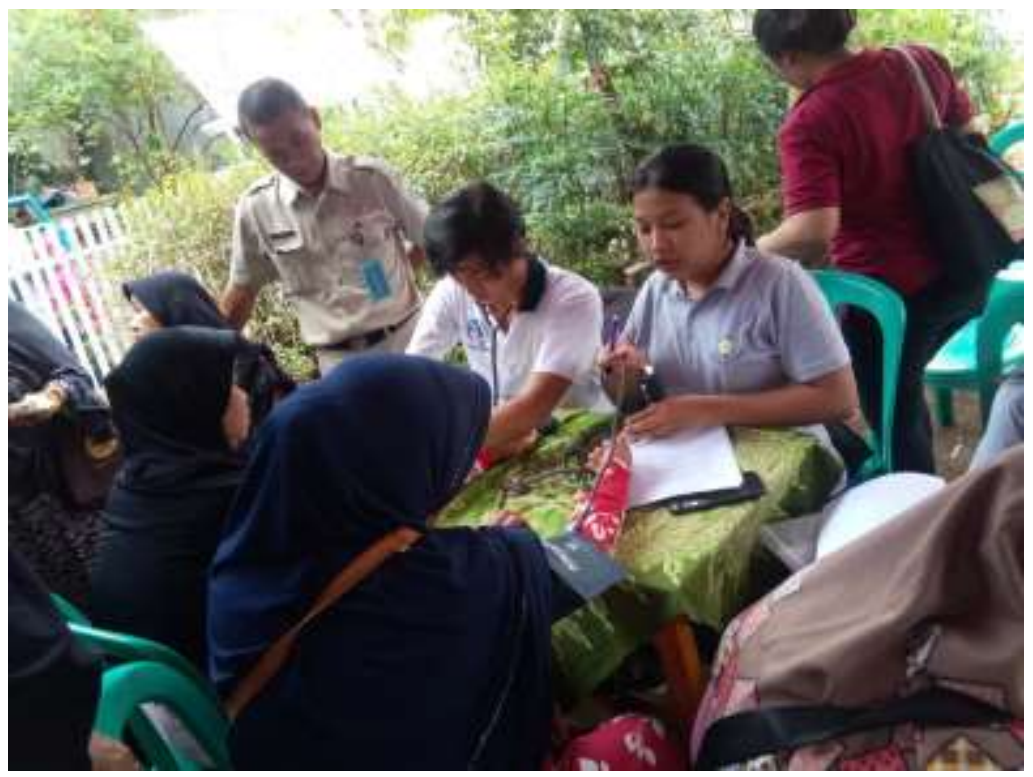

Foto 2.

Mahasiswa Fisioterapi melakukan pengecekan tekanan darah kepada para Lansia 


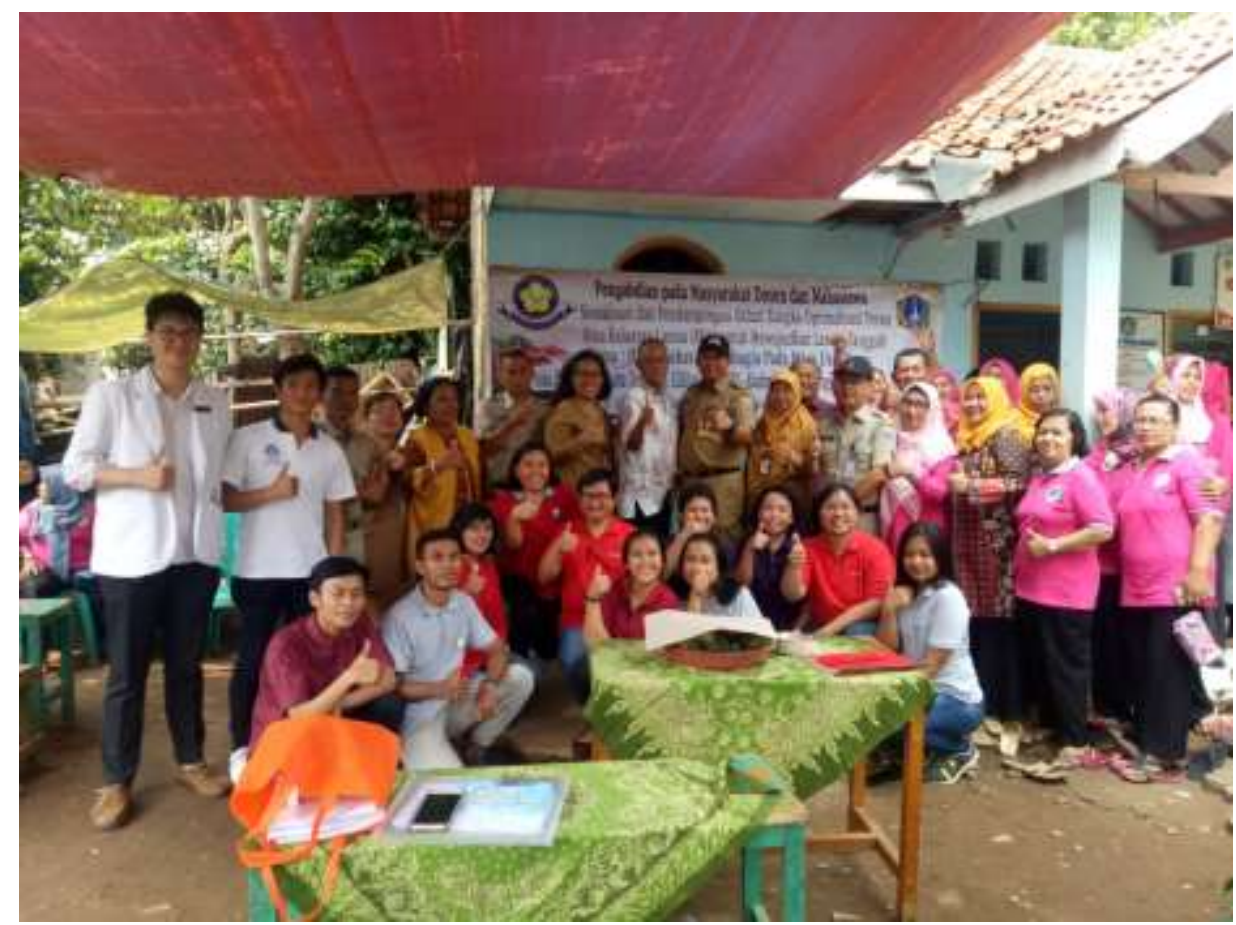

Foto 3.

Foto tim bersama dengan Kepala Lurah Kelurahan Cililitan, Ketua RW 05, Ketua PKB, utusan dari Sudin PPAPP Jakarta Timur

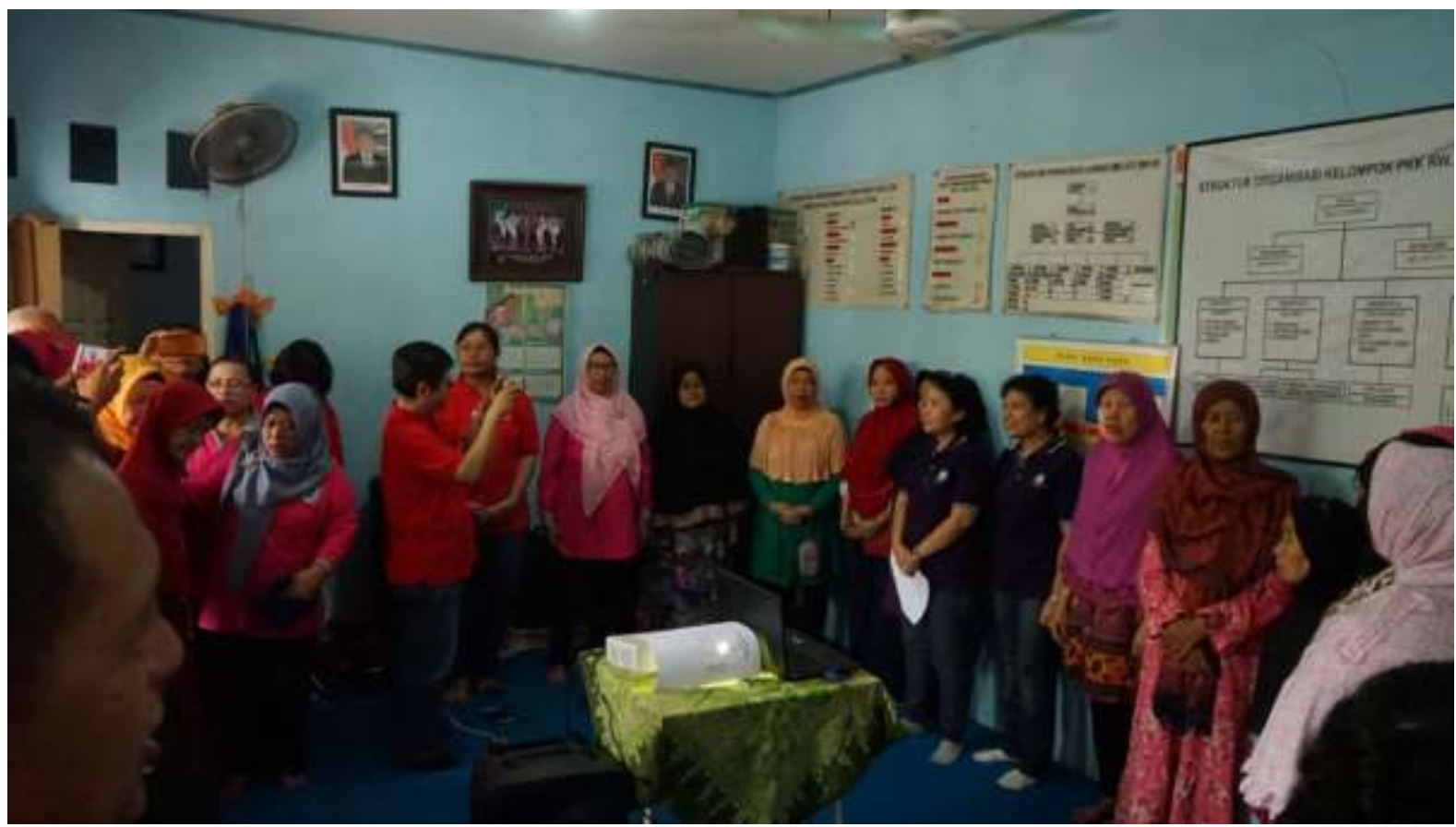

Foto 4.

Penyuluhan oleh Dosen Prodi Bimbingan Konseling FKIP UKI tentang bagaimana tetap bahagia menjalani usia emas 